\title{
Physicochemical characterization of the Ti-6Al-4V ELI alloy thermochemically treated with $\mathrm{NaOH}$
}

Caracterização físico-qúmica da liga Ti-6Al-4V ELI tratada termoquicamente com NaOH

Caracterización fisicoquímica de la aleación Ti-6Al-4V ELI tratada termoquímicamente con $\mathrm{NaOH}$

Received: 01/19/2022 | Reviewed: 01/27/2022 | Accept: 02/02/2022 | Published: 02/04/2022

\author{
Ana Elisa Vilicev Italiano \\ ORCID: https://orcid.org/0000-0003-4714-8478 \\ São Paulo State University, Brazil \\ E-mail: anevitaly@gmail.com \\ Artur José Carreira \\ ORCID: https://orcid.org/0000-0002-9995-284X \\ São Paulo Anhanguera University, Brazil \\ E-mail: dr.arturjcarreira@gmail.com \\ Alípio Pinto Pereira Guedes \\ ORCID: https://orcid.org/0000-0002-2146-7588 \\ São Paulo Anhanguera University, Brazil \\ E-mail: alipioppguedes@gmail.com \\ Daniela Vieira Amántea \\ ORCID: https://orcid.org/0000-0001-6749-2634 \\ São Paulo Anhanguera University, Brazil \\ E-mail: dvamantea1974@gmail.com \\ Luís Geraldo Vaz \\ ORCID: https://orcid.org/0000-0003-0916-0962 \\ São Paulo State University, Brazil \\ E-mail: lugervaz@ foar.unesp.br \\ Márcio Luiz dos Santos \\ ORCID: https://orcid.org/0000-0002-6607-1640 \\ São Paulo Anhanguera University, Brazil \\ E-mail: marcio.1.santos@educadores.net.br
}

\begin{abstract}
Titanium is a complex element and presents more than one crystallographic form, at room temperature it has a hexagonal crystal structure that transforms into a body-centered structure at $800^{\circ} \mathrm{C}$, and a melting point of $1670^{\circ} \mathrm{C} \pm$ $5^{\circ} \mathrm{C}$. Titanium alloys have superior mechanical properties to $\mathrm{Ti}$ c.p. in addition to excellent biocompatibility, a characteristic makes them the material of choice in orthopedic and dental applications. The alloy used in this study was the Ti-6Al-4V ELI alloy, obtained in cylindrical shape, sanded, and subsequently subjected to thermochemical treatment with $\mathrm{NaOH}$. The physicochemical characterization was performed by the techniques of X-ray fluorescenic spectrometry (XRF), scanning electron microscopy (SEM), X-ray diffractometry (XRD) and X-ray excited photoelectron spectroscopy (XPS). A biphasic structure ( $\alpha$ and $\beta$ ) and the formation of an alkali titanate hydrogel (sodium titanate $\left(\mathrm{Na}_{2} \mathrm{Ti}_{5} \mathrm{O}_{11}\right)$ ) on the surface were observed, due to the reaction of the $\mathrm{TiO}_{2}$ film with the $\mathrm{NaOH}$ solution. It is concluded the immersion of the samples in $\mathrm{NaOH}$, resulting in the crystallization of the titanate hydrogel layer, may favor the formation of calcium phosphates, as well as the bone/implant interaction.
\end{abstract}

Keywords: Ti-6Al-4V alloy; Treatment with $\mathrm{NaOH}$; Sodium titanate $\left(\mathrm{Na}_{2} \mathrm{Ti}_{5} \mathrm{O}_{11}\right)$.

\section{Resumo}

O titânio é um elemento complexo e apresenta mais de uma forma cristalográfica, à temperatura ambiente apresenta uma estrutura cristalina hexagonal que se transforma em uma estrutura de corpo centrado à $800^{\circ} \mathrm{C}$, e um ponto de fusão de $1670^{\circ} \mathrm{C} \pm 5^{\circ} \mathrm{C}$. As ligas de titânio apresentam propriedades mecânicas superiores ao Ti c.p. além de excelente biocompatibilidade, característica que a torna material de escolha em aplicações ortopédicas e odontológicos. A liga usada neste estudo foi a liga Ti-6Al-4V ELI, obtida em formato cilíndrico, lixadas e posteriormente submetidas ao tratamento termoquímico com $\mathrm{NaOH}$. A caracterização físico-química foi realizada pelas técnicas de espectrometria de fluorescênica de raios $X(X R F)$, microscopia eletrônica de varredura (MEV), difratometria de raios X (DRX) e espectroscopia de fotoelétrons excitados por raios X (XPS). Observou-se uma estrutura bifásica $(\alpha$ e $\beta$ ) e a formação de hidrogel de titanato alcalino (titanato de sódio $\left(\mathrm{Na}_{2} \mathrm{Ti}_{5} \mathrm{O}_{11}\right)$ ) sobre a superfície, devido a reação do filme de $\mathrm{TiO}_{2}$ com a solução $\mathrm{NaOH}$. Conclui-se que com a imersão das amostras em $\mathrm{NaOH}$ resultando na cristalização da camada de hidrogel de titanato, pode favorecer a formação de fosfatos de cálcio, bem como a interação osso/implante. 
Palavras-chave: Liga Ti-6Al-4V; Tratamento com $\mathrm{NaOH}$; Titanato de sódio $\left(\mathrm{Na}_{2} \mathrm{Ti}_{5} \mathrm{O}_{11}\right)$.

\section{Resumen}

El titanio es un elemento complejo y presenta más de una forma cristalográfica, a temperatura ambiente tiene una estructura cristalina hexagonal que se transforma en una estructura centrada en el cuerpo a $800^{\circ} \mathrm{C}$, y un punto de fusión de $1670^{\circ} \mathrm{C} \pm 5^{\circ} \mathrm{C}$. Las aleaciones de titanio tienen propiedades mecánicas superiores al Ti c.p. además de una excelente biocompatibilidad, característica que las convierte en el material de elección en aplicaciones ortopédicas y dentales. La aleación utilizada en este estudio fue la aleación Ti-6Al-4V ELI, obtenida en forma cilíndrica, lijada y posteriormente sometida a tratamiento termoquímico con $\mathrm{NaOH}$. La caracterización fisicoquímica se realizó mediante las técnicas de espectrometría fluorescente de rayos X (XRF), microscopía electrónica de barrido (SEM), difractometría de rayos X (XRD) y espectroscopía de fotoelectrones excitados por rayos X (XPS). Se observó una estructura bifásica $(\alpha$ y $\beta)$ y la formación de un hidrogel de titanato alcalino (titanato de sodio $\left(\mathrm{Na}_{2} \mathrm{Ti}_{5} \mathrm{O}_{11}\right)$ ) en la superficie, debido a la reacción de la película de $\mathrm{TiO}_{2}$ con la solución de $\mathrm{NaOH}$. Se concluye que la inmersión de las muestras en $\mathrm{NaOH}$, resultando en la cristalización de la capa de hidrogel de titanato, puede favorecer la formación de fosfatos de calcio, así como la interacción hueso/implante.

Palabras clave: Aleación Ti-6Al-4V; Tratamiento con $\mathrm{NaOH}$; Titanato de sodio $\left(\mathrm{Na}_{2} \mathrm{Ti}_{5} \mathrm{O}_{11}\right)$.

\section{Introduction}

Titanium is an allotropic element, that is, it exists in more than one crystallographic form. At room temperature, it has a compact hexagonal structure (hcp), called the $\alpha$ phase, which undergoes a crystalline transformation above the temperature of $882^{\circ} \mathrm{C}$, becoming a body-centered cubic (bcc) structure, called the $\beta$ phase, being stable up to the metal's melting point near $1672^{\circ}$ C.(Fonseca et al., 2017) Titanium alloys (Ti-6Al-4V) have mechanical properties superior to Ti cp (commercially pure titanium) and to other metallic alloys such as Co. Since then, they have been used in an increasing number of applications, in orthopedic and dental.(Jian-FengNie, 2014; Ohno et al., 2021)

Titanium and its alloys have excellent biocompatibility, due to a good resistance to corrosion in physiological fluids and an acceptable tissue tolerance, but in many cases, pure titanium is replaced by its alloys, with the Ti-6Al-4V alloy being the main material used.(Goto, 2014; Kuroda \& Nascimento, M V; Grandini, 2020)

The oxide layer, mainly $\mathrm{TiO}_{2}$, on the surface of titanium and its alloys plays a very important role in the favorable tissue response to the implant, as biocompatibility is determined by chemical processes that occur at the interface between the prosthesis and living tissue.(Albrektsson et al., 1987; Sasikumar et al., 2019)

Surface treatment techniques for materials such as titanium and its alloys have been proposed to create a biochemical reaction capable of accelerating the initial phases of bone tissue formation, which we call biointegration.(Feng et al., 1999) Studies show titanium metals subjected to $\mathrm{NaOH}$ and heat treatment have greater resistance, and can form apatite in a short period even in a living organism.(Feng et al., 1999; He et al., 2016; Ho et al., 2009)

In this work, the physicochemical reactions involving the surface activation of the commercial metallic alloy Ti-6Al$4 \mathrm{~V}$ ELI subjected to $\mathrm{NaOH}$ solution and thermochemical treatment were evaluated, aiming to favor the incorporation of chemical substances present in the inorganic part of the bone (phosphates of calcium) and provide better osseointegration.

\section{Methodology}

The Ti-6Al-4V ELI alloy (BALMER), in cylindrical shape, was sectioned in the longitudinal direction, to obtain samples with dimensions of $20 \mathrm{~mm}$ in diameter and $2 \mathrm{~mm}$ in thickness. Then proceeded the mechanical polishing using water sandpaper of granulation: 400 to 1000 and polishing with alumina of 1.0 and $0.3 \mu \mathrm{m}$. To reveal the microstructure, chemical etching was carried out with Kroll's reagent: $1 \mathrm{HF} 85 \%$ / $1 \mathrm{HNO}_{3} 65 \% / 100 \mathrm{H}_{2} \mathrm{O}$ (v/v).

To perform the surface activation and the topography and roughness tests, the surfaces of the Ti-6Al-4V alloy specimens were mechanically prepared by a 180 mesh SiC sandpaper, then cleaned in an alcohol and acetone solution. for 30 
minutes in ultrasound, washed with distilled water and dried. The specimens were subjected to a treatment in $\mathrm{NaOH}$ solution $\left(5.0 \mathrm{~mol} . \mathrm{L}^{-1}\right)$ for 24 hours at $60^{\circ} \mathrm{C}$. After this treatment, they were dried in an oven for 3 hours at $60^{\circ} \mathrm{C}$.

For the physicochemical characterization, we used some techniques such as: X-ray fluorescence spectrometry (XRF), Scanning electron microscopy (SEM), X-ray diffraction (XRD) and X-ray excited photoelectron spectroscopy (XPS). The Ti6Al-4V alloy specimens were analyzed in an Energy Dispersive X-Ray fluorescence spectrometer (EDX-800 RayNy), Shimadzu brand, which in this case has an EDS energy dispersive XRF system. The micromorphological analyzes on the Ti6Al-4V alloy were performed by SEM in the cross section of the Ti-6Al-4V samples, and performed with a JEOL-JSM microscope, model T-330 A, coupled with an energy spectroscopic analysis system. dispersive - EDS. To identify the phases present, we used: X-ray diffractometer SIEMENS D5000, with angular scan between 10 and $50^{\circ}$, in the Bragg-Brentano assembly, using $\mathrm{Cu}$ radiation (k $\alpha 1)$ and X-ray diffractometer of the Rigaku brand, model System D/MAX - 2100/PC, using K $\alpha$ radiation from copper $(1.5405 \mathrm{~A})$ with a Ni filter for K $\beta$ radiation with an ULTIMA theta-theta goniometer with a speed of 2 degrees $\mathrm{min}^{-1}$ being the source of Accelerated copper $\mathrm{K} \alpha$ radiation with a potential of $40 \mathrm{kV}$ and a current of $20 \mathrm{~mA}$ and angular sweep between $10^{\circ}$ and $50^{\circ}$, in the Bragg-Brentano setup.

For X-ray excited photoelectron (XPS) spectroscopy analysis, the surfaces of Ti-6Al-4V alloy thermochemically treated with $\mathrm{NaOH}$ were characterized in a Kratos Analytical spectromicroscope, model XSAM HS.

\section{Results}

\subsection{X-ray fluorescence spectrometry}

Table 1 presents the results of the X-ray fluorescence analysis for the Ti-6Al-4V alloy. The results showed that the concentrations are within the maximum ranges allowed by ASTM (American Society for Testing and Materials) standards specific to applications such as biomaterials.

Table 1 - Chemical composition of the Ti-6Al-4V ELI alloy (\% w / w).

\begin{tabular}{ccc}
\hline $\begin{array}{c}\text { ELEMENTS } \\
(\% \text { máx. })\end{array}$ & TI-6AL-4V & $\begin{array}{c}\text { Ti-6Al-4V ELI } \\
\text { (ASTM F136-98) }\end{array}$ \\
\hline $\mathrm{O}$ & - & 0.13 \\
\hline $\mathrm{N}$ & - & 0.05 \\
\hline $\mathrm{C}$ & - & 0.08 \\
\hline $\mathrm{H}$ & - & 0.12 \\
\hline $\mathrm{Ta}$ & 0.23 & - \\
\hline $\mathrm{Fe}$ & 6.5 & 0.25 \\
\hline $\mathrm{Al}$ & 3.2 & 5.5 a 6.5 \\
\hline $\mathrm{V}$ & - & 3.5 a 4.5 \\
\hline $\mathrm{Nb}$ & Control & Control \\
\hline $\mathrm{Ti}$ &
\end{tabular}

Sourche: Survey data. 


\subsection{Microscopic analysis of surfaces with and without thermochemical treatment}

The commercial alloy Ti-6Al-4V as received and etched with Kroll's reagent (microstructure development), showed a refined biphasic microstructure, where the light region is the $\alpha$ phase and the dark region the $\beta$ phase, Figure 1 ( $a$ and $b$ ).

Figure 1. Micrographs of the Ti-6Al-4V alloy (a) as received, (b) Attack with Kroll solution. Source: Survey data
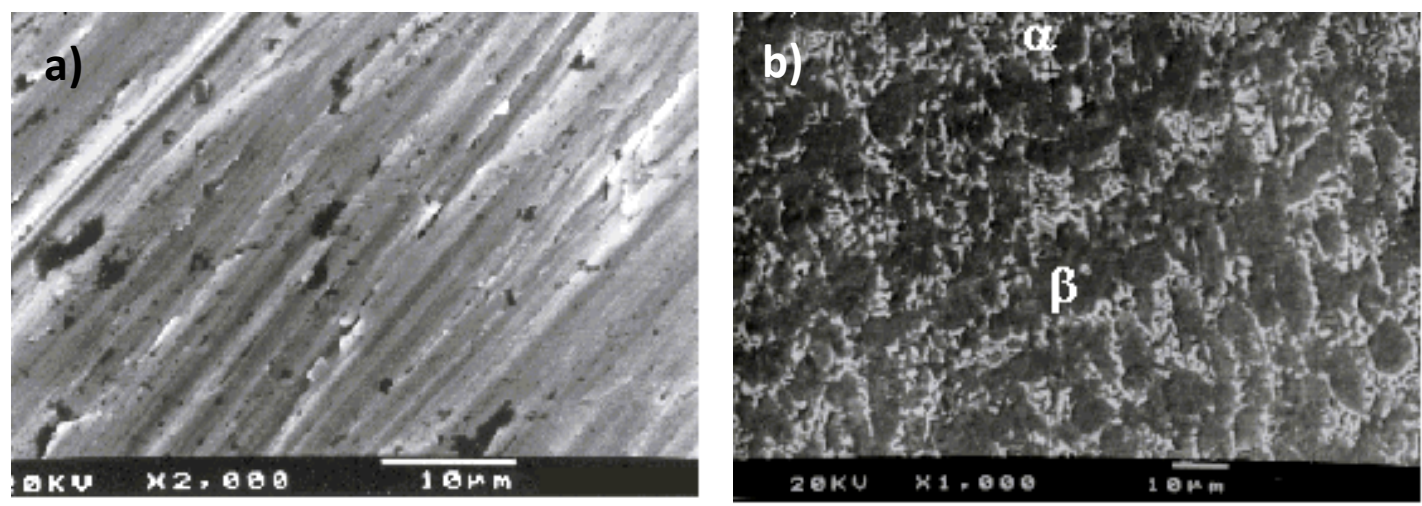

Sourche: Survey data.

In Figure 2, a morphology with the appearance of a microporous layer composed of an alkali titanate hydrogel formed during alkali/heat treatment can be seen.

Figure 2. SEM of the Ti-6Al-4V alloy surface after the thermochemical treatment with $\mathrm{NaOH}$ solution.

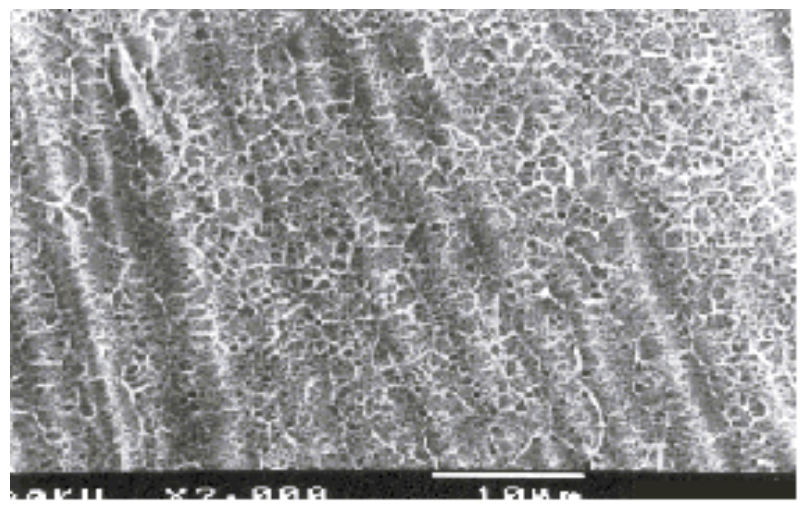

Sourche: Survey data.

\subsection{X-ray diffraction}

The X-ray diffractogram for the sample of the Ti-6Al-4V alloy showed peaks related to the hkl planes of the metallic Ti corresponding to the 44-1294 plug (JCPDS, 2003), Figure 3. The low concentration of the added elements, 6 and $4 \%$ (in mass) in the Ti-6Al-4V alloy, were not sufficient to be detected by X-ray diffraction. In the Ti-6Al-4V/NaOH occurred the formation of the sodium titanate layer on the surface of the Ti-6Ai-4V alloy, the phases $\mathrm{Na}_{4} \mathrm{Ti}_{5} \mathrm{O}_{11}$ were identified (n.52-1814) and the $\mathrm{NaTiO}_{3}$ phase (n.37-0345). 
Figure 3. X-ray diffractogram of Ti-6Al-4V and Ti-6Al-4V / NaOH alloy.
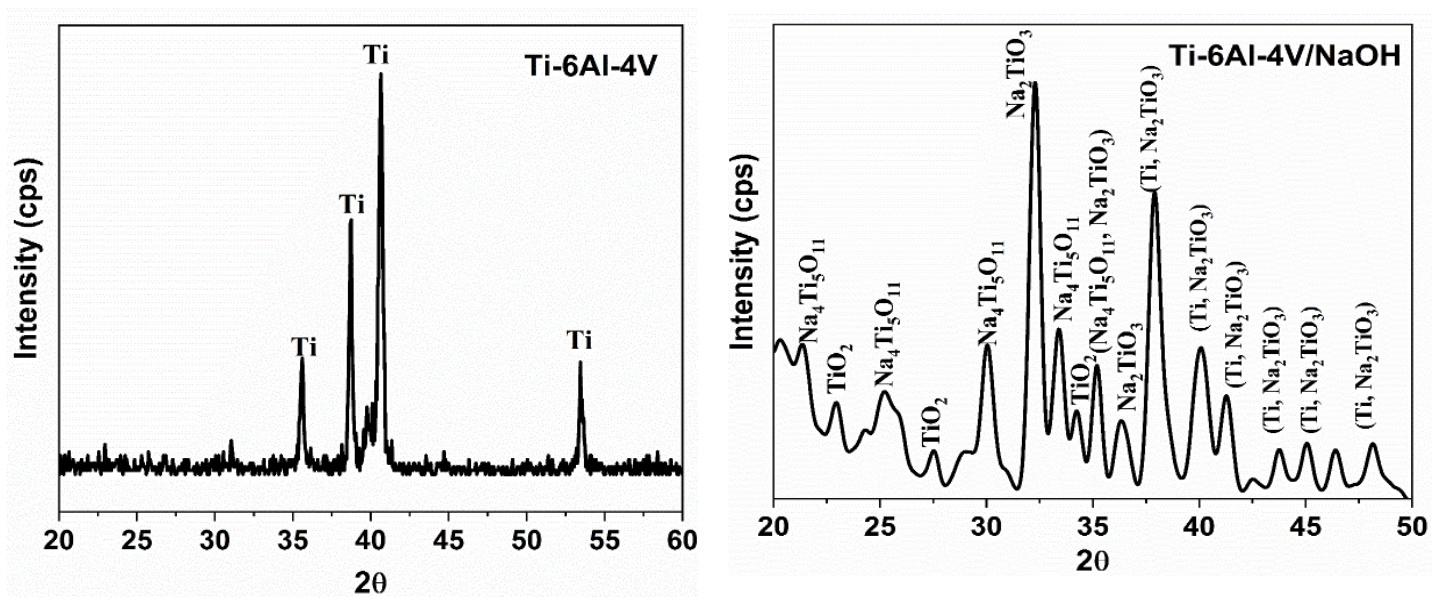

Sourche: Survey data.

\subsection{X-ray excited photoelectron spectroscopy (XPS)}

Figure 4 corresponds to the XPS spectra of the elements found on the surface of the Ti-6Al-4V/NaOH sample. It can be observed the binding energies of $\mathrm{Na} 1 \mathrm{~s}$ and $\mathrm{Ti} 2 \mathrm{p} 3 / 2,1071.5 \mathrm{eV}$ and $458.5 \mathrm{eV}$ for Ti-6Al-4V (Table 2).

Figure 4. XPS spectra of the Ti-6Al-4V alloy surface attacked with a $5 \mathrm{~mol}$. $\mathrm{L}^{-1} \mathrm{NaOH}$ solution. Source: Survey data
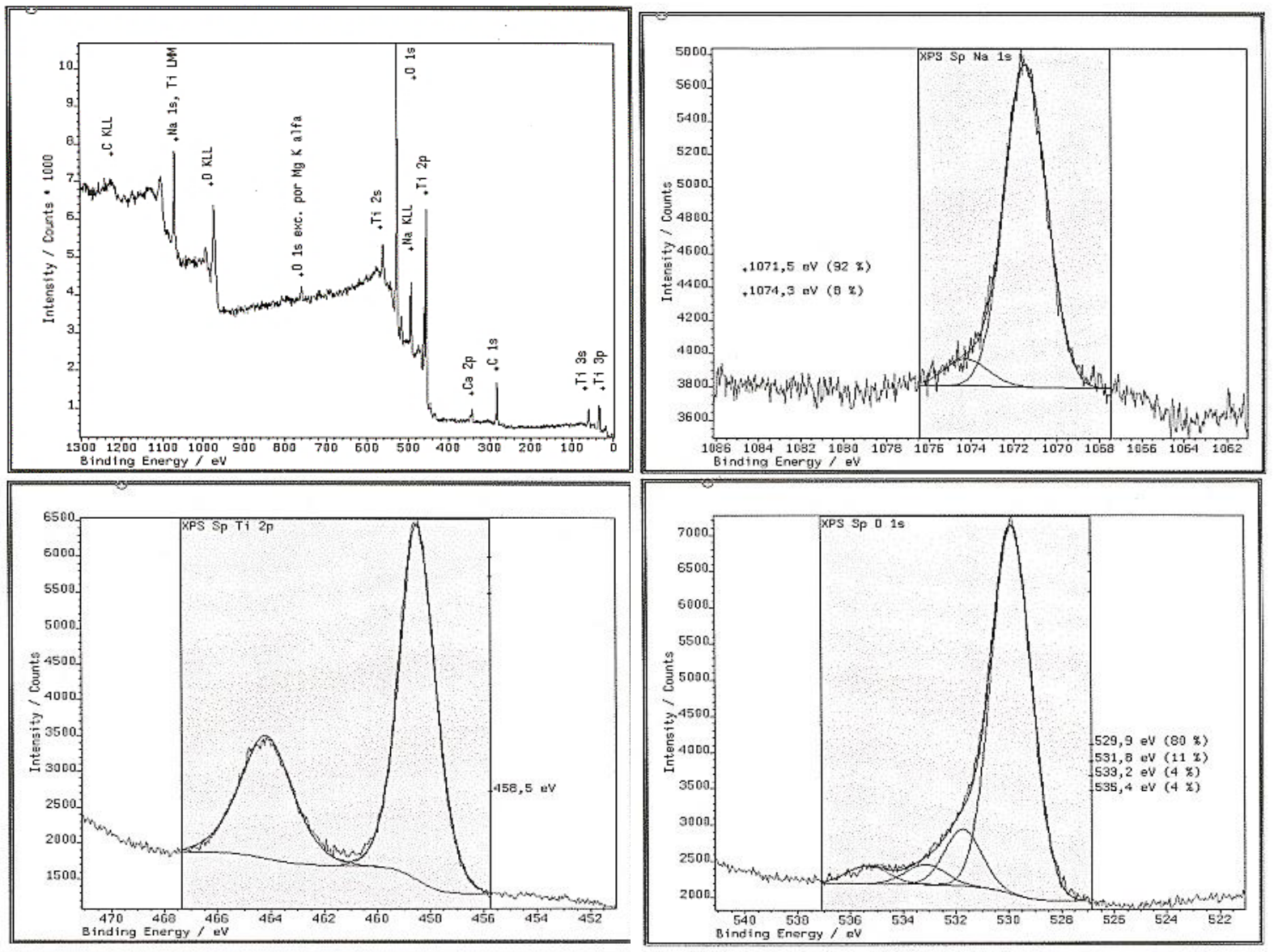

Sourche: Survey data. 
The carbon detected in the analysis appears to be the contaminant on the surfaces analyzed by XPS, in this case mainly due to the samples having been cleaned with acetone. Generally, these impurities are removed by ion bombardment with Ar+ during the cleaning process. In this case, this method was not chosen because this type of cleaning can change the oxidation state.

Table 2. Values of the connection energies $(\mathrm{eV})$ of the components of the main photoelectric peaks. The percentages in parentheses refer to the relative quantities of each component of the respective peak.

\begin{tabular}{|c|c|c|c|c|}
\hline \multirow[t]{2}{*}{ Sample } & \multicolumn{4}{|c|}{ Link energy (eV) } \\
\hline & $\mathrm{C} 1 \mathrm{~s}$ & $\mathrm{O} 1 \mathrm{~s}$ & $\operatorname{Ti} 2 \mathrm{p} 3 / 2$ & $\mathrm{Na} 1 \mathrm{~s}$ \\
\hline \multirow{4}{*}{$\mathrm{Ti}-6 \mathrm{Al}-4 \mathrm{~V} / \mathrm{NaOH}$} & $284.8(70 \%)$ & $529.9(80 \%)$ & $458.5(100 \%)$ & $1071.5(92 \%)$ \\
\hline & $286.4(17 \%)$ & $531.8(11 \%)$ & & $1074.3(8 \%)$ \\
\hline & $288.6(13 \%)$ & $533.2(4 \%)$ & & \\
\hline & & $535.4(4 \%)$ & & \\
\hline
\end{tabular}

Sourche: Survey data.

\section{Discussion}

In agreement with some studies of the vast literature about titanium alloys, we emphasize that the Ti6Al4V alloy is the material that presents the most suitable properties for use in biomedical devices.

The study presented in the microscopic analysis a refined biphasic microstructure, suggesting that it is due to the presence of aluminum which is a $\alpha$ stabilizer and vanadium which is a $\beta$ stabilizer and to the thermomechanical process in which the alloy was submitted during manufacture. (Kumar \& Ramamurty, 2019) The passive layer of titanium oxide that forms on the untreated alloy is very stable. However, this $\mathrm{TiO}_{2}$ layer can react with a $\mathrm{NaOH}$ solution and form an alkali titanate hydrogel on the surface.(T. Kokubo, 1996; Oh et al., 2014; Shahriyari et al., 2018) This layer is dehydrated and stabilized as a partially crystallized sodium titanate after treatment at $60^{\circ} \mathrm{C}$ for 3 hours. According to studies after chemical attack, titanate has a gel structure(Gil et al., 2002; Kizuki et al., 2014; Tadashi Kokubo \& Yamaguchi, 2015; Oh et al., 2014; Shahriyari et al., 2018), which is partially crystallized(Kim et al., 1997; Tadashi Kokubo \& Yamaguchi, 2015) for sodium titanate $\left(\mathrm{Na}_{2} \mathrm{Ti}_{5} \mathrm{O}_{11}\right)$ and rutile $\left(\mathrm{TiO}_{2}\right)$.(M. T. Mohammed et al., 2015; Shahriyari et al., 2018; Takadama et al., 2001)

During treatment with sodium hydroxide, the surface is partially dissolved to form an alkaline solution due to the corrosive attack of the hydroxyl groups. (Gil et al., 2002; H. I. Mohammed et al., 2015; Oh et al., 2014)

This reaction occurs simultaneously with the hydration of the metallic Ti:

(1) $\mathrm{Ti}+3 \mathrm{OH}^{-} \Leftrightarrow \mathrm{Ti}(\mathrm{OH})_{3}{ }^{+}+4 \mathrm{e}-$

(2) $\mathrm{Ti}(\mathrm{OH})_{3}{ }^{+}+\mathrm{OH}^{-} \Leftrightarrow \mathrm{Ti}(\mathrm{OH})_{4}$

An additional attack of the hydroxyl to a hydrated $\mathrm{TiO}_{2}$ will produce negatively charged hydrates on the surface of the substrate.

(3) $\mathrm{TiO}_{2} \cdot \mathrm{nH}_{2} \mathrm{O}+\mathrm{OH}^{-} \Leftrightarrow \mathrm{HTiO}_{3}{ }^{-} \mathrm{nH}_{2} \mathrm{O}$

According to researchers, the high temperature of heat treatment $\left(>60^{\circ} \mathrm{C}\right)$ after immersion of the samples in $\mathrm{NaOH}$ results in the crystallization of the hydrogel layer, reducing ionic activity and decreasing the rate of nucleation and formation of calcium phosphates of biological interest.(Hsu et al., 2010; Kizuki et al., 2013; Ma et al., 2003) 
In the studies by Feng et al, the binding energies $458.22 \mathrm{eV}$ and $458.39 \mathrm{eV}$ are associated with the formation of $\mathrm{TiO}_{2}$.(Feng et al., 1999; Hsu et al., 2010; Krzakała et al., 2013) Oxygen on the titanium surface in a humid environment can exist in three states: $\mathrm{TiO}_{2}$, basic Ti-OH and acidic Ti-OH or $\mathrm{H}_{2} \mathrm{O}$. As other studies identified the appearance of three peaks with binding energies of 532.7; 531.3 and 529.5eV which may be associated with Ti-OH.(Hsu et al., 2010; Krzakała et al., 2013; Mao et al., 1999) The binding energy 529.5 and 529.9 of O1s may be associated with the basic Ti-OH state, as this is more active in the chemical reaction. Therefore, based on the data obtained and, on the literature, consulted, it can be said that the formation of $\mathrm{TiO}_{2}$ and sodium titanate is probably occurring on the surfaces studied.(Feng et al., 1999; Hsu et al., 2010; Krzạkała et al., 2013)

XPS analyzes on Ti-6Al-4V alloy without etching were not performed because the objective was to understand the transformations that occurred on the surface treated with $\mathrm{NaOH}$.

\section{Conclusion}

The results of this study corroborate works described in the literature and allow us to conclude that the biomimetic crystallization of the hydroxylated surface of the commercial alloy Ti-6Al-4V, which results from the thermochemical treatment with alkaline $\mathrm{NaOH}$ solution, in an organized arrangement of Ti-OH with hydroxyl groups chemically adsorbed, it can induce the growth of phosphates (HA), favoring the bone / implant interaction.

The authors suggest other studies with surface modification of titanium alloys, using calcium phosphate coating, with the objective of improving the bone/implant interaction, allowing a specific biological response in the osseointegration process.

\section{References}

Albrektsson, T., Brånemark, P. I., Jacobsson, M., \& Tjellström, A. (1987). Present clinical applications of osseointegrated percutaneous implants. In Plastic and Reconstructive Surgery (Vol. 79, Issue 5, pp. 721-730). https://doi.org/10.1097/00006534-198705000-00007

Feng, Q. L., Wang, H., Cui, F. Z., \& Kim, T. N. (1999). Controlled crystal growth of calcium phosphate on titanium surface by NaOH-treatment. Journal of Crystal Growth, 200(3), 550-557. https://doi.org/10.1016/S0022-0248(98)01402-X

Fonseca, Y., Crema de Almeida, A. C., Fernandes, D., Elias, C., \& Monteiro, E. (2017). Mechanical Properties of Ti-47Nb and Ti-30Nb-8Zr Alloys. 24th ABCM International Congress of Mechanical Engineering. https://doi.org/10.26678/abcm.cobem2017.cob17-1016

Gil, F. J., Padrós, A., Manero, J. M., Aparicio, C., Nilsson, M., \& Planell, J. A. (2002). Growth of bioactive surfaces on titanium and its alloys for orthopaedic and dental implants. Materials Science and Engineering C, 22(1), 53-60. https://doi.org/10.1016/S0928-4931(01)00389-7

Goto, T. (2014). Osseointegration and dental implants. Europe PMC, 24(2), 265-271. https://doi.org/clica1402265271

He, D., Liu, P., Liu, X., Ma, F., Chen, X., Li, W., Du, J., Wang, P., \& Zhao, J. (2016). Characterization of hydroxyapatite coatings deposited by hydrothermal electrochemical method on $\mathrm{NaOH}$ immersed Ti6Al4V. Journal of Alloys and Compounds, 672, 336-343. https://doi.org/10.1016/j.jallcom.2016.02.173

Ho, W. F., Lai, C. H., Hsu, H. C., \& Wu, S. C. (2009). Surface modification of a low-modulus Ti-7.5Mo alloy treated with aqueous NaOH. Surface and Coatings Technology, 203(20-21), 3142-3150. https://doi.org/10.1016/j.surfcoat.2009.03.042

Hsu, H. C., Wu, S. C., Fu, C. L., \& Ho, W. F. (2010). Formation of calcium phosphates on low-modulus Ti-7.5Mo alloy by acid and alkali treatments. Journal of Materials Science, 45(13), 3661-3670. https://doi.org/10.1007/s10853-010-4411-x

Jian-FengNie. (2014). Physical Metallurgy of Light Alloys. Physical Metallurgy, 2009-2156. https://doi.org/https://doi.org/10.1016/B978-0-444-53770$6.00020-4$

Kim, H. M., Miyaji, F., Kokubo, T., \& Nakamura, T. (1997). Effect of heat treatment on apatite-forming ability of Ti metal induced by alkali treatment. Journal of Materials Science: Materials in Medicine, 8(6), 341-347. https://doi.org/10.1023/A:1018524731409

Kizuki, T., Matsushita, T., \& Kokubo, T. (2014). Antibacterial and bioactive calcium titanate layers formed on Ti metal and its alloys. Journal of Materials Science: Materials in Medicine, 25(7), 1737-1746. https://doi.org/10.1007/s10856-014-5201-9

Kizuki, T., Takadama, H., Matsushita, T., Nakamura, T., \& Kokubo, T. (2013). Effect of Ca contamination on apatite formation in a Ti metal subjected to $\mathrm{NaOH}$ and heat treatments. Journal of Materials Science: Materials in Medicine, 24(3), 635-644. https://doi.org/10.1007/s10856-012-4837-6

Kokubo, T. (1996). Formation of biologically active bone-like apatite on metals and polymers by a biomimetic process. Thermochimica Acta, 280-281(SPEC. ISS.), 479-490. https://doi.org/10.1016/0040-6031(95)02784-X 
Research, Society and Development, v. 11, n. 2, e50211225915, 2022

(CC BY 4.0) | ISSN 2525-3409 | DOI: http://dx.doi.org/10.33448/rsd-v11i2.25915

Kokubo, Tadashi, \& Yamaguchi, S. (2015). Bioactive Titanate Layers Formed on Titanium and Its Alloys by Simple Chemical and Heat Treatments. The Open Biomedical Engineering Journal, 9(1), 29-41. https://doi.org/10.2174/1874120701509010029

Krzạkała, A., Kazek-Kęsik, A., \& Simka, W. (2013). Application of plasma electrolytic oxidation to bioactive surface formation on titanium and its alloys. In RSC Advances. https://doi.org/https://doi.org/10.1039/C3RA43465F

Krzakała, A., Słuzalska, K., Dercz, G., Maciej, A., Kazek, A., Szade, J., Winiarski, A., Dudek, M., Michalska, J., Tylko, G., Osyczka, A. M., \& Simka, W. (2013). Characterisation of bioactive films on Ti-6Al-4V alloy. Electrochimica Acta, 104, 425-438. https://doi.org/10.1016/j.electacta.2012.12.081

Kumar, P., \& Ramamurty, U. (2019). Microstructural optimization through heat treatment for enhancing the fracture toughness and fatigue crack growth resistance of selective laser melted Ti-6Al-4V alloy. Acta Materialia, 169, 45-59. https://doi.org/10.1016/j.actamat.2019.03.003

Kuroda, P. A. B., \& Nascimento, M V; Grandini, C. R. (2020). Preparação e caracterização de uma liga de titânio com a adição de tântalo e zircônio para aplicações biomédicas Preparation and characterization of a titanium alloy with the addition of tantalum and zirconium for biomedical applications. Revista Materia, 25(2). https://doi.org/10.1590/s1517-707620200002.1041

Ma, J., Wong, H., Kong, L. B., \& Peng, K. W. (2003). Biomimetic processing of nanocrystallite bioactive apatite coating on titanium. Nanotechnology, 14(6), 619-623. https://doi.org/10.1088/0957-4484/14/6/310

Mao, C., Li, H., Cui, F., Ma, C., \& Feng, Q. (1999). Oriented growth of phosphates on polycrystalline titanium in a process mimicking biomineralization. Journal of Crystal Growth, 206(4), 308-321. https://doi.org/10.1016/S0022-0248(99)00315-2

Mohammed, H. I., Carradò, A., \& Abdel-Fattah, W. I. (2015). Noble metals role in autocatalytic phosphate coatings on TAV alloys. I.Ag functionalization of autocatalytic phosphate deposition on TAV alloys. Surface and Coatings Technology, 282, 171-179. https://doi.org/10.1016/j.surfcoat.2015.10.003

Mohammed, M. T., Khan, Z. A., Geetha, M., \& Siddiquee, A. N. (2015). Microstructure, mechanical properties and electrochemical behavior of a novel biomedical titanium alloy subjected to thermo-mechanical processing including aging. Journal of Alloys and Compounds, 634, 272-280. https://doi.org/10.1016/j.jallcom.2015.02.095

Oh, J. M., Roh, K. M., Kwon, H., Lee, B. K., Suh, C. Y., \& Lim, J. W. (2014). Preparation of Ti ternary alloys by addition of Si to Ti-Mo alloy scraps for carbonitride application. Materials Transactions, 56(1), 167-170. https://doi.org/10.2320/matertrans.M2014285

Ohno, K., Tsuchiya, M., Kuwahara, R., Sahara, R., Bhattacharyya, S., \& Pham, T. N. (2021). Study on Ni-Ti alloys around equiatomic composition by the first-principles phase field method. Computational Materials Science, 191(December 2020), 110284. https://doi.org/10.1016/j.commatsci.2021.110284

Sasikumar, Y., Indira, K., \& Rajendran, N. (2019). Surface Modification Methods for Titanium and Its Alloys and Their Corrosion Behavior in Biological Environment: A Review. Journal of Bio- and Tribo-Corrosion, 5(2), 0. https://doi.org/10.1007/s40735-019-0229-5

Shahriyari, F., Razaghian, A., Taghiabadi, R., Peirovi, A., \& Amini, A. (2018). Effect of friction hardening pre-treatment on increasing cytocompatibility of alkali heat-treated Ti-6Al-4V alloy. Surface and Coatings Technology, 353(August), 148-157. https://doi.org/10.1016/j.surfcoat.2018.08.051

Takadama, H., Kim, H. M., Kokubo, T., \& Nakamura, T. (2001). XPS study of the process of apatite formation on bioactive Ti-6Al-4Valloy in simulated body fluid. Science and Technology of Advanced Materials, 2(2), 389-396. https://doi.org/10.1016/S1468-6996(01)00007-9 